\title{
The Impact of Gender Differences on Job Satisfaction of University Library Professionals
}

\author{
M.P.L.R. Marasinghe ${ }^{1}$, Anusha Wijayaratne ${ }^{2}$
}

\begin{abstract}
This study examined the influence of gender on job satisfaction among university library professionals in Sri Lanka. Survey design was adopted for the study. The general objective of the study was to evaluate the effect of gender differences on the level of job satisfaction among the professional staff of the university libraries in Sri Lanka. Five parameters were considered. They were work, co-workers, compensation, promotion and supervision. The population of the study consisted of 125 library professionals of 15 universities under the University Grants Commission in Sri Lanka. All members of the population were given the opportunity to participate in the study. A semi-structured questionnaire was used as the main data collection instrument. The response rate was 64\%. Cronbach's alpha values of all variables are above 0.6 (work: 0.764, co-workers: 0.864, compensation: 0.661, promotion: 0.614 and supervision: 0.963). The instrument used to measure each variable in the current study is reliable and all the items are positively correlated to one another. The mean of job satisfaction of all aspects: work; co-workers; compensation; promotion and supervision is higher in Females (0.9200, 0.8021, 0.6521, 0.6667, 0.7243) than males $(0.7277,0.6406,0.5250$, $0.3854,-0.0052)$. The results indicated that there is a significant difference of job satisfaction between male and female university library professionals only in the "supervision" parameter. The overall job satisfaction of both male and female (3.77) university library professionals is equal. However, equal treatment to both genders will help to achieve higher satisfaction levels. The findings of the study will be helpful for librarians and administrators to develop a motivated and productive workforce for organizational success.
\end{abstract}

Keywords: Gender differences, Job satisfaction, Library professionals, Sri Lanka, University libraries,

1 Senior Assistant Librarian, Faculty of Medicine, University of Kelaniya. Email: lakmini@kln.ac.lk, (D) https://orcid.org/0000-0001-9929-7112

2 Former Senior Assistant Librarian, Open University of Sri Lanka

Received: 27 April 2018, Accepted revised version: 9 July 2018. 


\section{Introduction}

The library is an important unit of the university to fulfill the information needs of academic staff and students of the university by providing information resources required for the educational and research programs. User satisfaction is the main purpose of the library. Therefore, the library professionals in the university should play an important role and it is essential to maintain a high level of job satisfaction among the library professionals in order to provide commendable library service to the user community. If they are not satisfied with their job, it directly affects the organization because no organization can successfully achieve its goal and mission unless and until those who constitute the organization is satisfied with their jobs. There are numerous definitions for the perception of job satisfaction. Job satisfaction is generally defined as a person's evaluation of his/her job and work context. Job satisfaction is a result of an individual's perception and evaluation of their job influenced by their own unique needs, values and expectations (Sempane, Rieger \& Roodt, 2002). Somvir and Kaushik (2012) defined the job satisfaction as an emotional response to a job situation which cannot be seen, it is only be inferred and simply how the people feel about their job and different aspects of it and it refers to the way one feels about events, rewards, people, relation and amount of mental gladness on the job. Hulin and Judge (2003) noted that job satisfaction includes multidimensional psychological responses to one's job, and that such responses have cognitive (evaluative), affective (emotional), and behavioral components.

If the employees who cannot meet their expectations with regard to their jobs, it becomes dissatisfied and this dissatisfaction decreases the quality and the productivity of the organization for which he or she works. Job satisfaction of librarians is essential to rendering better library services to users. Besides, the level of job satisfaction of the librarians affects the user satisfaction too. At an international level, several researchers (Kaba, 2017; Khan, Masrek \& Nadzar, 2017; Sultana \& Begum, 2012; Somvir \& Kaushik, 2012; Hsu, 2009; Karim, 2008) carried out studies on the job satisfaction of university library professionals with the relationship of sex, age, tenure, education, etc. 
Haque, Karim, Muqtadir, and Anam (2012) described through their study that the factors affecting job satisfaction can be categorized into personal and organizational factors and personal factors are age, gender, religion and race. Leadership, organizational change and technological innovation, continuous professional development (CPD), recruitment, rotation, retention, working environment, communication and commitment, salary and stress are the organizational factors.

Job satisfaction of library professionals is essential and a fundamental determinant of the development and organization of the service because in general all are efficient, when they are satisfied with their jobs. It has been revealed by researchers (Nadjla \& Hasan, 2009; Ogunlana, Okunlaya, Ajani, Okunoye, \& Oshinaike, 2013; Wahba, 1975; Amune, 2014; Memon \& Jena, 2017) that job satisfaction of library professionals was affected by the gender. In situations, where either gender is dissatisfied with their jobs, it could have an adverse effect on the smooth running of the library leading to absenteeism, high rate of staff turnover and low productivity. Therefore, the level of job satisfaction of library professionals with the effect of sex difference is questionable and there is also a risk for declining status of job satisfaction among the professional librarians in universities. The current study is focusing the job satisfaction with the gender of the professionals in university libraries in Sri Lanka. The level of job satisfaction of the professional staff of the university libraries of Sri Lanka was evaluated with five parameters namely; work, co-workers, compensation, promotion and supervision. The information and understanding of job satisfaction of university library professionals' is very important. If there are differences and similarities of job satisfaction associated with sex differences, then it is critical to understand what they specifically are and where the variations are greatest. This study aims at bridging the part of this the gap by production of the comprehensive picture on job satisfaction in respect to sex differences of university library professionals in Sri Lanka. Job satisfaction of the librarians will affect the quality of the service they render and it is the condition of establishing a healthy organizational environment in an organization or a library. It is important for a person's motivation and contribution to production. The data generated of this study will be helpful for librarians and administrators to understand the level of job satisfaction of the university 
library professionals based on the sex differences and the reasons for it. The set of guidelines that have been desired based on the findings would be useful to develop a motivated and productive workforce for organizational success by enhancing the level of job satisfaction of the professional staff of the university libraries in Sri Lanka.

\section{Research Objectives}

In order to find out the level of impact of selected five parameters on the job satisfaction among male and female university library professionals of Sri Lanka and the differences and similarities on the job satisfaction among male and female university library professionals of Sri Lanka, the study aimed to:

i. Identify the level of job satisfaction between male and female university library professionals in Sri Lanka

ii. Evaluate the effect of gender differences on the level of job satisfaction among the professional staff of the university libraries in Sri Lanka with five parameters namely: work; coworkers; compensation; promotion and supervision

iii. Examine the impact of the gender differences on the overall job satisfaction among the professional staff of the university libraries in Sri Lanka

Further, following null hypotheses are tested in this study.

Ho1: There is no difference in the level of job satisfaction between male and female university library professionals presently in the workforce.

Hoa: There is no difference in the level of job satisfaction between male and female university library professionals presently in the workforce in the perception of the work performed.

Hob: There is no difference in the level of job satisfaction between male and female university library professionals presently in the workforce in the perception of co-workers.

Hoc: There is no difference in the level of job satisfaction between male and female university library professionals presently in the workforce in the perception of compensation. 
Hod: There is no difference in the level of job satisfaction between male and female university library professionals presently in the workforce in the perception of promotion.

Hoe: There is no difference in the level of job satisfaction between male and female university library professionals presently in the workforce in the perception of supervision.

\section{Literature Review}

Job satisfaction of employees of an organization is essential for the organizational success. Job motivation, organizational commitment, performance, turnover and absenteeism have a direct impact on an organizational effectiveness (Singh \& Tiwari, 2011; Kim, 2001; Hussin, 2011; Medina, 2012; Kehinde, 2011).

There are many motivational theories that evolved throughout the last 70 years. These theories are important to build a better workforce of an organization. These include Maslow's hierarchy of needs theory, Herzberg's two factor theory, Discrepancy theories, Adams equity theory and McClelland's need theory, etc. There are theories; feminist theory, gender equity theory, to describe the nature of gender differences too.

Abraham Maslow proposed that employees' needs determine their level of job satisfaction and classified human needs into five different levels such as physiological needs (eating, drinking, resting, etc.), security needs (pension, health insurance, etc.), the need to love (good relation with the environment, friendship, fellowship, to love and to be loved), need for self-esteem (selfconfidence, recognition, adoration, to be given importance, status, etc.) and need of self-actualization (maximization of the latent power and capacity, development of abilities, etc.) (Maslow, 1943).

Herzberg's two factor theory and Maslow's hierarchy of needs theory are in contrast. Herzberg's theory was built upon two separate sets of conditions, satisfiers and dis-satisfiers. Herzberg's two factor theory is based on a study of accountants and engineers. As a result of this study, it identified that job satisfaction was associated with positive intrinsic sources related to the content of the job such as achievement, recognition, work itself, 
responsibility, and advancement which Herzberg termed motivators. Job dissatisfaction stemmed from negative extrinsic sources relating to the context of the job such as company policy, administration, supervision, salary, recognition and relation with supervisor and peers which were labelled as hygiene factors (Wickremasinghe, 2011).

The Discrepancy theory describes that job satisfaction is a result of a comparison between the perception of the current situation and some standard of comparison (Boyd, Huang, Jiang, \& Klein, 2007). Adams equity theory suggests that persons who work in an organization compare themselves with others in an equivalent position to determine if they are being treated fairly.

Therefore, there are various kind of research done by scientists in various part of the world that show and support the fact that there are a large number of the factors that are playing a very vital and an important role in affecting the job satisfaction. These parameters or factors can be related to the organization called as the organizational factors followed by the work environmental factors, personal factors and many more.

An employee's overall satisfaction with his job is the result of a combination of factors. In this study, only five key parameters have been selected because work, co-workers, compensation, promotion and supervision are considered as the most significant parameters that contribute to the job satisfaction. In this study a personal factor, gender is used as the independent variable.

Many researchers have been carried out to examine the job satisfaction of university librarians with the effect of sex differences. Findings regarding sex differences are inconsistent. Some studies (Nadjla \& Hasan, 2009; Ogunlana et al., 2013; Wahba, 1975) investigated that males are more satisfied than females, but some studies (Amune, 2014) investigated the opposite: females are more satisfied than males. Some researchers (Ghiasi \& Limoni, 2015; Onuoha, Samuel \& Ojo, 2014; Mirfakhrai, 1991; Somvir \& Kaushik, 2012; Wong \& Heng, 2009) have reported that there are no differences between sexes regarding job satisfaction. 
Adio and Popoola (2010) investigated that there is a significant relationship between gender and career commitment of librarians in federal university libraries in Nigeria and the further stated that librarians were dissatisfied with physical working conditions, job recognition, job security, promotion, social status, wages, social services, authority, and responsibility. Ogunlana et al. (2013) affirmed that there is a significant difference in job stress between male and female librarians in the same working environment. Mirfakhrai (1991) studied correlates of job satisfaction among librarians in the U.S. and the study investigated that academic librarians in both smaller and larger libraries had a positive perception of their jobs and there was no significant relationship between sex of academic librarians and their overall satisfaction in both sized libraries. Wahba (1975) compared the job satisfaction of male and female librarians in 23 academic libraries and the results indicated that women are more dissatisfied than men in the perception of security, esteem, autonomy and self-actualization with the exception of social needs. The study further stated that male librarians give more importance to the personal development and free decision making in their jobs than the female librarians.

There are only a handful of studies (Thirunavukarasu, 1994; Amarakoon, 1995; Kuruppu, 1998; Wijeweera, 2004) carried out on job satisfaction of professional staff of university libraries of Sri Lanka. Among these researchers, the studies (Amarakoon, 1995; Wijeweera, 2004) have taken "sex" as a dependent variable to evaluate the job satisfaction of university librarians with limited sample size. Job satisfaction of both professionals and paraprofessionals of agricultural libraries in Sri Lanka was studied by Wijeweera (2004) and the result indicated that females are more attracted to the library profession than males. A lot of changes have been taken place since that time. This study aims at evaluating the job satisfaction of university library professionals in Sri Lanka with the impact of sex based on five parameters which have not been attempted by the previous researchers.

\section{Methodology}

This study aims at identifying the impact of gender for the level of job satisfaction of the university library professionals including all members of academic staff of the library (i.e. Librarian, Deputy Librarian, Senior 
Assistant Librarian Grade I, Senior Assistant Librarian Grade II, and Assistant Librarian) presently in the workforce. There are many factors influenced for the job satisfaction. In this study, only five key parameters have been selected: because work, co-workers, compensation, promotion and supervision are the main key parameters that affect for the job satisfaction. Therefore, the current study aims at identifying the impact of gender based on five parameters which have not been attempted by the previous researchers.

These five parameters have been treated as dependent variables and sex differences (male/female) are the independent variables. The survey research design was adopted for this study. A quantitative methodology was selected for this study to measure job satisfaction of the respondents relating to five satisfaction dimensions. Survey method has been used for this study since $12^{\text {th }}$ December 2013 to $21^{\text {st }}$ January 2014. The study population was made up of 125 library professionals of 15 universities under University Grants Commission (UGC) in Sri Lanka (UGC, 2015). Sampling was enumerative as all members of the population were given the opportunity to participate in the study. Therefore, the sample size (125) of the study is equal to the population size. A self-administered semi-structured questionnaire was used as the data collecting instrument. In addition, a pilot study was carried out with the participation of six library professionals in the Main Library, University of Kelaniya, Sri Lanka during the first week of December 2013.

The survey instrument was divided into 2 main sections; ' $A$ ' (Demographic information) and ' $B$ ' (Job satisfaction with regard to work, coworkers, compensation, promotion, supervision). Section $A$ targeted to obtain the data on demographic information of the respondents while section $B$ targeted to obtain the participants' preferences on job satisfaction with regard to work, coworkers, compensation, promotion and supervision. Section $A$ was composed with 5 questions (i.e. A1 for age, A2 for gender, A3 for working experience, $A 4$ for job title and $A 5$ for the highest professional qualification) and section $B$ was subdivided into 3 sub sections (i.e. $B 1, B 2$ and $B 3$ ). $B 1$ was composed with 5 main categories with 28 statements (i.e. $B 1.1$ for work including 8 statements or items, $B 1.2$ for coworkers including 6 statements or items, $B 1.3$ for compensation including 5 statements or items, $B 1.4$ for 
promotion including 3 statements or items and $B 1.5$ for supervision including 6 statements or items) using a 5-point Likert scale as the rating mechanism from Strongly agree to No opinion. B2 was to make additional comments of the respondents on 5 key dimensions of job satisfaction and B3 was to mention the overall job satisfaction of the respondents.

The data were organized using Excel 2013 and SPSS (Statistical Package for the Social Sciences) version 16 has been used to analyze the data in order to achieve the research objectives via answering the research questions. Data were analyzed using descriptive and inferential statistics. Cronbach's alpha coefficient was estimated to use as the measure of internal consistency indicator of reliability and Independent Samples Test was used for statistical testing to determine the differences among males and females.

\section{Results}

Out of 125 copies of the questionnaire distributed, 80 were retrieved with the response rate of $64 \%$. Out of 80 respondents of the current study, 48 (60\%) were females and $32(40 \%)$ were males.

\section{Reliability Analysis}

Cronbach's alpha $(\alpha)$ is the most widely used objective measure of reliability among variables. A commonly accepted range of the Cronbach's alpha value for scale items with the level of reliability (internal consistency) (George \& Mallery, 2003) is: $\alpha \geq 0.9$ Excellent; $0.7 \leq \alpha<0.9$ Good; $0.6 \leq \alpha<0.7$ Acceptable; $0.5 \leq \alpha<0.6$ Poor; $\alpha<0.5$ Unacceptable. Cronbach's alphas were calculated for the job satisfaction scores using the sample of the study $(N=80)$ as in Table 1 . It denotes that Cronbach's alpha values of all variables are above 0.6 ranged from 0.614 to 0.963 . Cronbach's alpha for the supervision score was greater than 0.9 (0.963), indicating an 'excellent' level of reliability (internal consistency) of the results. Cronbach's alpha for the work score was 0.764 and co-workers score was 0.864 , indicating a "good" level of reliability of the results. The Cronbach's alpha values of both compensation and promotion were 0.661 and 0.614 respectively and the level of reliability of results is acceptable. 


\section{Table 1. Summary of reliability analysis}

\begin{tabular}{|c|c|c|}
\hline No. & Variable & $\begin{array}{c}\text { Cronbach's } \\
\text { alpha } \\
(\mathrm{N}=80)\end{array}$ \\
\hline 1.0 & Job Satisfaction: Work & 0.764 \\
\hline 1.1 & My job gives me an opportunity to gather new skills. & \\
\hline 1.2 & My work is personally rewarding. & \\
\hline 1.3 & I find my work interesting. & \\
\hline 1.4 & I am bored with my job most of the time. & \\
\hline 1.5 & I have the resources I need to do my job. & \\
\hline 1.6 & I have skills to perform my duties efficiently and effectively. & \\
\hline 1.7 & I receive the right amount of recognition for my work. & \\
\hline 1.8 & I get the fullest support from the University administration to perform my duties. & \\
\hline 2.0 & Job Satisfaction: Co-workers & 0.864 \\
\hline 2.1 & I am satisfied with the work performance of the fellow staff. & \\
\hline 2.2 & There is good cooperation among members of my workgroup. & \\
\hline 2.3 & My fellow staff communicate sufficiently with me. & \\
\hline 2.4 & My subordinates are honest \& obedient. & \\
\hline 2.5 & They are concerned about my work. & \\
\hline 2.6 & It is easy to work with my subordinates & \\
\hline 3.0 & $\underline{\text { Job Satisfaction: Compensation }}$ & 0.661 \\
\hline 3.1 & I am satisfied that my pay reflects the effort I put into my work. & \\
\hline 3.2 & I have been receiving the same recognition as other academic staff do. & \\
\hline 3.3 & $\begin{array}{l}\text { University administration treats me like other academic staff in all occasions like } \\
\text { convocations etc. }\end{array}$ & \\
\hline 3.4 & I am not satisfied with the salary I get. & \\
\hline 3.5 & I have opportunity to participate in staff welfare activities. & \\
\hline 4.0 & $\underline{\text { Job Satisfaction: Promotion }}$ & 0.614 \\
\hline 4.1 & My job responsibilities contribute to my professional development. & \\
\hline 4.2 & I am satisfied with the promotion scheme. & \\
\hline 4.3 & Administrative barriers are minimum in getting my promotions & \\
\hline 5.0 & Job Satisfaction: Supervision & 0.963 \\
\hline 5.1 & My supervisor regularly gives me feedbacks on my work performance. & \\
\hline 5.2 & My supervisor’s guidance is helpful for me to perform my work. & \\
\hline 5.3 & I get clear instructions from my supervisor. & \\
\hline 5.4 & My supervisor guides me to perform at my best. & \\
\hline 5.5 & $\begin{array}{l}\text { I receive the appreciation, guidance } \& \text { encouragement from my supervisor whenever } \\
\text { it is needed. }\end{array}$ & \\
\hline 5.6 & Generally, my supervisor does a good job. & \\
\hline
\end{tabular}


The instrument used to measure each variable in the current study is reliable and all the items are positively correlated to one another. Further, it is internally consistent. Hence, the reliability of the job satisfaction scores is not a limitation of the current study.

\section{Satisfaction with Job Satisfaction Scores}

Table 2 and Figure 1 indicate that the mean of job satisfaction of all aspects; work, co-workers, compensation, promotion and supervision is higher in Females $(0.9200,0.8021,0.6521,0.6667,0.7243)$ than males $(0.7277$, $0.6406,0.5250,0.3854,-0.0052)$ respectively. The difference between male and female of library professionals in the perception of supervision is slightly higher than other perceptions (work, co-workers, compensation).

Table 2. Means of job satisfaction scores with gender

\begin{tabular}{llllll}
\hline \multirow{2}{*}{ Gender } & \multirow{5}{*}{ Work } & Coworkers & Compensation & Promotion & Supervision \\
\hline Male & 0.7277 & 0.6406 & 0.5250 & 0.3854 & -0.0052 \\
Female & 0.9200 & 0.8021 & 0.6521 & 0.6667 & 0.7243 \\
\hline
\end{tabular}

Figure 1 clearly shows that the level of job satisfaction among male and female university library professionals.

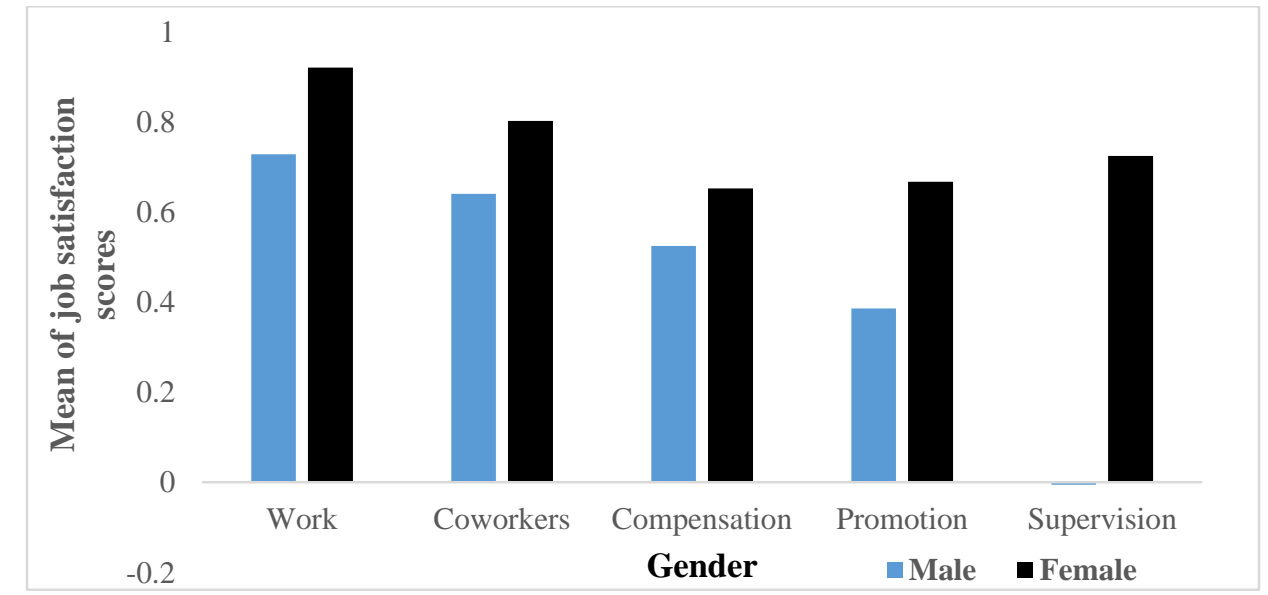

Figure 1. Mean of job satisfaction scores among male and female university library professionals 
Table 3 indicates the statistics for "supervision" and Figure 2 shows the error bar of mean value of supervision by gender.

Table 3. Group statistics for supervision

\begin{tabular}{lllll}
\hline Gender & $\mathrm{N}$ & Mean & $\begin{array}{l}\text { Standard } \\
\text { deviation }\end{array}$ & $\begin{array}{l}\text { Standard error } \\
\text { mean }\end{array}$ \\
\hline Male & 32 & -0.0052 & 1.37338 & 0.24278 \\
Female & 48 & 0.7243 & 0.83348 & 0.12030 \\
\hline
\end{tabular}

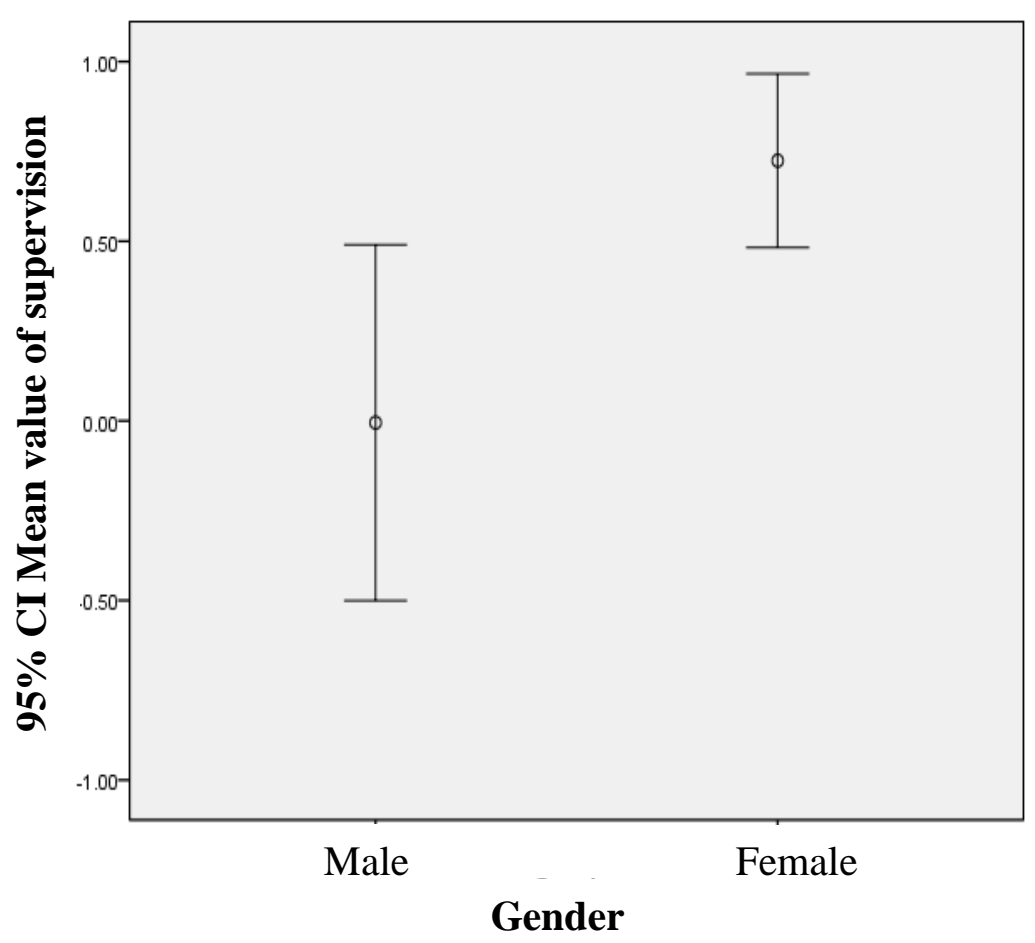

Figure 2. Error bar of mean value of supervision by gender

Results of the independent sample test is presented in Table 4. 
Table 4. Independent samples test for job satisfaction scores

\begin{tabular}{|c|c|c|c|c|c|c|c|c|}
\hline \multirow{2}{*}{ 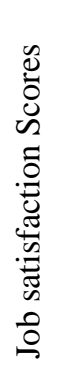 } & \multirow[b]{2}{*}{$\begin{array}{l}\text { Equal variances } \\
\text { assumed/not } \\
\text { assumed }\end{array}$} & \multicolumn{3}{|c|}{$\begin{array}{l}\text { Levene's test for } \\
\text { equality of } \\
\text { variances }\end{array}$} & \multicolumn{4}{|c|}{ t-test for equality of means } \\
\hline & & $\mathrm{F}$ & 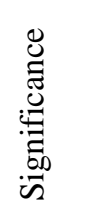 & $\mathrm{t}$ & df & 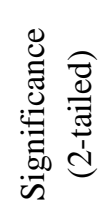 & 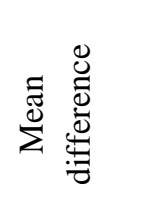 & 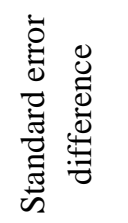 \\
\hline \multirow{2}{*}{ 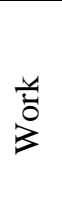 } & $\begin{array}{l}\text { Equal variances } \\
\text { assumed }\end{array}$ & 4.086 & 0.047 & -1.419 & 78 & 0.160 & -0.19234 & 0.13557 \\
\hline & $\begin{array}{l}\text { Equal variances } \\
\text { not assumed }\end{array}$ & 0.000 & 0.000 & -1.333 & 52.476 & 0.188 & -0.19234 & 0.14428 \\
\hline \multirow{2}{*}{ 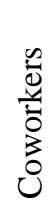 } & $\begin{array}{l}\text { Equal variances } \\
\text { assumed }\end{array}$ & 2.324 & 0.131 & -0.963 & 78 & 0.339 & -0.16146 & 0.16767 \\
\hline & $\begin{array}{l}\text { Equal variances } \\
\text { not assumed }\end{array}$ & 0.000 & 0.000 & -0.907 & 52.886 & 0.369 & -0.16146 & 0.17810 \\
\hline \multirow{2}{*}{ 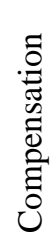 } & $\begin{array}{l}\text { Equal variances } \\
\text { assumed }\end{array}$ & 0.038 & 0.847 & -0.814 & 78 & 0.418 & -0.12708 & 0.15603 \\
\hline & $\begin{array}{l}\text { Equal variances } \\
\text { not assumed }\end{array}$ & 0.000 & 0.000 & -0.802 & 63.078 & 0.425 & -0.12708 & 0.15842 \\
\hline \multirow{2}{*}{$\begin{array}{l}\text {.0 } \\
.0 \\
0 \\
0 \\
0\end{array}$} & $\begin{array}{l}\text { Equal variances } \\
\text { assumed }\end{array}$ & 0.682 & 0.411 & -1.560 & 78 & 0.123 & -0.28125 & 0.18031 \\
\hline & $\begin{array}{l}\text { Equal variances } \\
\text { not assumed }\end{array}$ & 0.000 & 0.000 & -1.533 & 62.626 & 0.130 & -0.28125 & 0.18343 \\
\hline \multirow{2}{*}{ 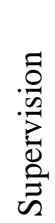 } & $\begin{array}{l}\text { Equal variances } \\
\text { assumed }\end{array}$ & 20.356 & 0.000 & -2.957 & 78 & 0.004 & -0.72951 & 0.24667 \\
\hline & $\begin{array}{l}\text { Equal variances } \\
\text { not assumed }\end{array}$ & 0.000 & 0.000 & -2.692 & 46.253 & 0.010 & -0.72951 & 0.27095 \\
\hline
\end{tabular}


Testing Hypotheses:

Hoa:

According to the Table 4, the significance (sig.) of Levene's Test for Equality of Variances related to the Work score is 0.047 , but the relevant value of sig. (2-tailed) under t-test for equality of means is (0.188) higher than 0.05 . Therefore, the null hypothesis (Hoa) cannot be rejected.

Hob:

The sig. of Levene's Test for Equality of Variances related to the coworkers is 0.131 and sig.(2-tailed) value is (0.339) not less than 0.05 . The hypothesis Hob cannot be rejected.

Hoc:

The results indicate that that the sig. Levene's Test for Equality of Variances related to the compensation is 0.847 and the relevant sig. (2-tailed) is 0.418 , higher than 0.05 . The hypothesis Hoc cannot be rejected.

Hod:

The sig. value of Levene's Test for Equality of Variances in the perception of promotion is 0.411 and sig. (2-tailed) is $>0.05$ (0.123). Therefore, Hod cannot be rejected.

Hoe:

In the perception of supervision, the sig. of Levene's Test for Equality of Variances is 0.000 and the relevant sig. (2-tailed) is 0.010 , less than 0.05 . Therefore, the null hypothesis of Hoe can be rejected.

The results indicated that there is a significant difference of job satisfaction between male and female university library professionals only in the "supervision" parameter, whereas no gender differences existed in other four parameters. Statistically, in the perception of supervision, the female $(0.7243, \mathrm{SD}=0.83)$ university library professionals have a significantly larger average job satisfaction than males $(-0.0052, \mathrm{SD}=1.37)$ as indicated in Table 3. 


\section{The Level of Job Satisfaction}

The mean for the level of job satisfaction on gender are shown in Table 5 and Figure 3. Only females (6.25) responded that they are fully dissatisfied. The level of job satisfaction indicated as "dissatisfied to some extent", "average" and "satisfied to some extent" by males $(6.25,25,46.87)$ is higher than females $(4.16,18.75,45.83)$ respectively. The mean value for the level of job satisfaction as "fully satisfied" is higher in females (22.91) than males (15.62).

Table 5. The mean for the level of gender differences of job satisfaction among university library professionals

\begin{tabular}{lcc}
\hline Level of job satisfaction & Female & Male \\
\hline Fully dissatisfied & 6.25 & 0 \\
Dissatisfied to some extent & 4.166667 & 6.25 \\
Average & 18.75 & 25 \\
Satisfied to some extent & 45.83333 & 46.875 \\
Fully satisfied & 22.91667 & 15.625 \\
\hline
\end{tabular}

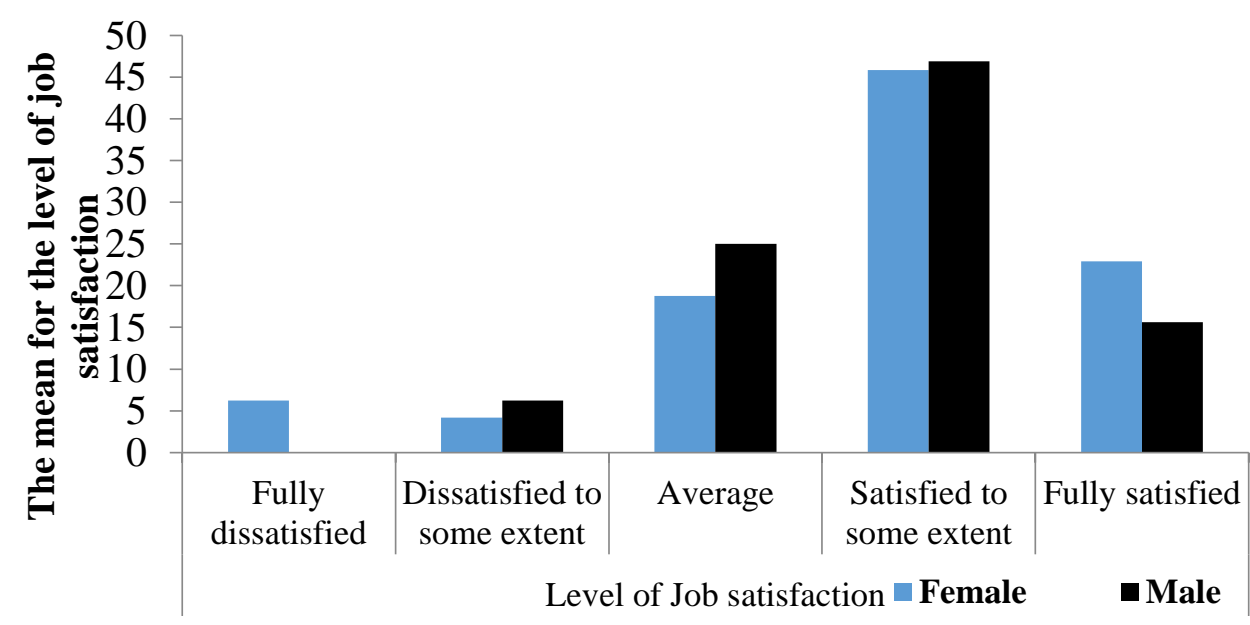

Figure 3. The level of job satisfaction among male and female university library professionals 
According to the descriptive statistics, the mean value for the overall job satisfaction is 3.77 both in males and females. Although there are some differences, the overall job satisfaction of both male and female university library professionals is equal.

\section{Discussion}

The female university library professionals have a larger average job satisfaction on "supervision" than males. There are some differences between male and female university library professionals in other parameters: work; coworkers; compensation and promotion, but statistically, there are no any significant differences between male and female university library professionals. These distinctions and similarities are very important to create stronger and productive workforces. Especially, library administrators should have the great responsibility to avoid job dissatisfaction due to gender discrimination. Gender discrimination is a constraint for job satisfaction and the job satisfaction is an important factor in academic library management.

\section{Conclusion and Recommendations}

There is a significant difference of job satisfaction between male and female university library professionals only in the "supervision" parameter, whereas no gender differences existed in other four parameters (work, co-workers, compensation and promotion). There are some variations among males and females on the level of job satisfaction, but considering the overall job satisfaction both have the equal level of job satisfaction.

Library administrators should treat equally for each gender in order to avoid job dissatisfaction due to gender discrimination. The opportunities or facilities such as scholarships, training programs (local/ foreign), conferences, seminars, workshops, etc. should be introduced equally for male and female university librarians. They should be encouraged to do research and facilitated to conduct or organize academic activities such as workshops, training programs, seminars, and lectures for their professional development. The university administrators should facilitate to provide good working environment to the library academics to enhance their job efficiently and effectively without gender bias. Job rotation can be recommended to 
both academic and non-academic staff of the library. Especially the supervision should be done equally for each gender. Regular feedback, better guidance and encouragement by the supervisors are very important in improving the job performance. They should be acknowledged about the modern methods of human resource management.

The same study can be carried out for the librarians in non UGC universities, institutions, school and public libraries in Sri Lanka. The level of job satisfaction can be evaluated by other variables such as working experience, educational qualifications and job title, etc. The study can be extended to investigate the job satisfaction of librarians with related to other job satisfaction parameters such as working environment, policies, job security, status, achievement, responsibility, advancement, etc.

\section{References}

Adio, G., \& Popoola, S. O. (2010). Demographic variables and self- efficacy as factors influencing career commitment of librarians in federal university libraries in Nigeria. Library Philosophy and Practice (EJournal), Paper no. 329. Retrieved from http://digitalcommons.unl.edu/libphilprac/329

Amarakoon, L. R. (1995). Study to determine the job satisfaction of health sciences librarians in Sri Lanka (Unpublished fellowship thesis). Sri Lanka Library Association, Colombo, Sri Lanka.

Amune, J. B. (2014). A comparative study of the determinants of job satisfaction among male and female librarians in public university libraries in Edo State of Nigeria. International Journal of Education and Research, 2(7), 649-660.

Boyd, M., Huang, S., Jiang, J. J. \& Klein, G. (2007). Discrepancies between desired and perceived measures of performance of IS professionals: views of the IS professionals themselves and the users. Information and Management, 44, 188-195.

Ghiasi, M., \& Limoni, S. T. (2015). Investigating the factors affecting the level of job satisfaction among the librarians at Central Library of Islamic Azad University of District 3. Library Philosophy and Practice, Paper 1350, 1-3. Retrieved from 
http://digitalcommons.unl.edu/cgi/viewcontent.cgi?article=3668\&context $=$ libphilprac

George, D., \& Mallery, P. (2003). SPSS for Windows step by step: A simple guide and reference (4th ed.). Boston: Allyn \& Bacon.

Haque, M., Karim, A. N. M., Muqtadir, A. \& Anam, S. (2012). Dimensions of job satisfaction of library professionals: A qualitative exploration. International Journal of Business and Social Research, 2(5), 46-62.

Hsu, C. (2009). The organizational commitments and job satisfaction of librarians in university libraries. (Unpublished Master's Thesis). Nanhua University, Dalin Township, Taiwan.

Hulin, C. L., \& Judge, T. A. (2003). Job attitudes. In: W. C. Borman, D. R. ligen and R. J. Klimoski (Eds.). Handbook of psychology: Industrial and organizational psychology. Retrieved from http://www.timothyjudge.com/Job\%20Satisfaction\%20and\%20Subjectiv e\%20Well-Being-Judge\%20\&\% 20Klinger.pdf

Hussin, A. B. (2011). The relationship between job satisfaction and job performance among employees in Tradewinds Group of Companies. (Unpublished master's thesis). Open University Malaysia, Kuala Lumpur, Malaysia.

Kaba, A. (2017). Library employment: Satisfaction, opportunities, and future actions as perceived by academic librarians. Library Management, 38(8/9), 511-527.

Karim, N. H. A. (2008). Investigating the correlates and predictors of job satisfaction among Malaysian librarians. Malaysian Journal of Library and Information Science, 13(2), 69-88.

Kehinde, A. O. (2011). Impact of job satisfaction on absenteeism: A correlative study. European Journal of Humanities and Social Sciences, 1(1), 25-49.

Khan, A., Masrek, M. N. F., \& Nadzar, M. (2017). Emotional intelligence and job satisfaction of academic librarians: An assessment of the relationship. Journal of Librarianship and Information Science, 49(2), 199-210. 
Kim, B. S. (2001). Commitment of Malaysian workers in Korean multinational enterprises. Malaysian Management Review, 36(1), 63-75.

Kuruppu, D. C. (1998). How to maximize the job satisfaction of professional librarians? Sri Lanka Library Review, 12(2), 71-78.

Maslow, A. (1943). A theory of human motivation. Psychological Review, 50(4), 370-396.

Medina, E. (2012). Job satisfaction and employee turnover intention: What does organizational culture have to do with it? (Unpublished master's thesis). Columbia University, New York, United States.

Memon, N. Z., \& Jena, L. K. (2017). Gender inequality, job satisfaction and job motivation: Evidence from Indian female employees. Management and Labour Studies, 42(3), 1-22.

Mirfakhrai, M. H. (1991). Correlates of job satisfaction among academic librarians in the United States. Journal of Library Administration, 14(1), $117-31$.

Nadjla, H., \& Hasan, A. R. (2009). Gender differences and job satisfaction of the Iranian public librarians. Studies in Library and Information Science (Journal of Education and Psychology), 16(3), 112-191.

Ogunlana, E. K., Okunlaya, R. O. A., Ajani, F. O., Okunoye, T., \& Oshinaike, A.O. (2013). Indices of job stress and job satisfaction among academic librarians in selected federal universities in South West Nigeria. Annals of Library and Information Studies, 60, 212-218.

Onuoha, U. D., Samuel, T. D., \& Ojo, A. I. (2014). Gender and job satisfaction: a study of library staff in private university libraries in Ogun state Nigeria. Journal of New Media and Mass Communication, 1(1), 1219.

Sempane, M. E., Rieger, H. S., \& Roodt, G. (2002). Job satisfaction in relation to organizational culture. SA Journal of Industrial Psychology, 28(2), 23-30.

Singh, S. K., \& Tiwari, V. (2011). Relationship between motivation and job satisfaction of the white collar employees: A case study. Management 
Insight, 7(2), 32-39.

Somvir, \& Kaushik, S. (2012). International Journal of Scientific and Research Publications, 2(5), 1-4.

Sultana, F., \& Begum, B. (2012). Measuring the job satisfaction of female library professionals working in the health libraries in Dhaka city. The Eastern Librarian, 23(1), 37-50.

Thirunavukarasu, K. (1994). Job satisfaction among university professional librarians in Sri Lanka, (Unpublished master's thesis). University of Colombo, Colombo, Sri Lanka.

University Grants Commission - Sri Lanka (2015). Universities and higher educational institutions. Retrieved from http://www.ugc.ac.lk/en/universities-and-institutes/universities.html

Wahba, S. P., (1975). Job satisfaction of librarians: A comparison between men and women, College and Research Libraries. 36, 45-51.

Wickremasinghe, M. T. P. (2011). An empirical study on the impact of hygiene and motivation factors on job satisfaction of bank executives in Western Province, Sri Lanka (Unpublished master's thesis). University of Kelaniya, Kelaniya, Sri Lanka.

Wijeweera, K. G. G., (2004). Job satisfaction of professionals and in agricultural libraries in Sri Lanka (Unpublished master's thesis). University of Colombo, Colombo, Sri Lanka.

Wong, E. S. K. \& Heng, D. T. N., (2009). Case study of factors influencing job satisfaction in two Malaysian universities. International Business Research, 2(2), 86-98. 